\title{
i-Maties: Indonesian Translation on an Instrument for Teachers Attitudes Towards Inclusive Education
}

\author{
Khofidotur Rofiah* \\ ${ }^{1}$ Uniwersytet Pedagogiczny im. Komisji Edukacji Narodowej w Krakowie, Krakow, Poland \\ *Corresponding author. Email: khofidotur.rofiah@doktorant.up.krakow.pl
}

\begin{abstract}
A cross-cultural study has been performed for decades to enhance inclusive education across diverse cultures and groups. However, even with instruments explicitly built for cross-cultural research, researchers encounter translation challenges from the source language to the target language. Thus, translation is critical in order to maintain conceptual, content, semantic, and construct equivalences between the two languages and cultures, which is necessary for the measurement results to be credible. This article aims to discuss the process by which the Multidimensional Attitudes towards Inclusive Education Scale (MATIES) was translated and cross-culturally adapted. It was translated into Bahasa Indonesia by using Guellimin's step. The difficulties associated with certain wordings and cultural variations encountered in daily life were identified and resolved, resulting in the development of an adequate version of the tool that is ready for further research with teachers in Indonesian inclusive education.
\end{abstract}

Keywords: Inclusive education, Teacher attitude, Instrument translation, Cross-cultural adaptation.

\section{INTRODUCTION}

Inclusive education assumes that schools must meet the needs of all children, regardless of disability or handicap. It implies that children with disabilities attend regular schools and classrooms with their classmates of the same age and get teaching that meets their educational requirements. Inclusive education aims to guarantee that children with disabilities are treated as full members of the classroom learning community, with their unique needs addressed [1]. In Indonesia, establishing an inclusive education system across Indonesia is a social undertaking that is especially difficult. Indonesia, whose national motto is Bhinneka Tunggal Ika ('unity in diversity,') is the world's largest archipelagic country with more than 17, 524 islands and a population of more than 270 million people, making it the world's most diverse multi-ethnic state [2].

Teacher perspectives affect practices in the classroom [3]. While the push for 'inclusive education' is part of a broader human rights agenda, many teachers have grave concerns about the extensive inclusion of students with special educational needs in regular schools [4]. The teachers' perspectives who have primary responsibility for executing the policy, are an important factor in its successful implementation. Teachers and their attitudes are critical in ensuring that inclusive education for everyone takes place in the 'real- world' situations and settings [10].

International, national, and state policies have resulted in significant changes in the provision of educational services to persons with disabilities. These developments have resulted in a shift away from greater integration of children with disabilities into mainstream schools toward creating an inclusive educational environment for everyone. Over the last few decades, researchers have determined that teachers' attitudes are a critical factor in the effectiveness of inclusive education [6].

In most cases, instruments must be adapted for usage in a nation with a distinct culture and language. Except for a few measures, all existing measures are written in English and are designed for usage in English-speaking nations. Nonetheless, there is a need for solutions tailored to non-English speaking nations [5].

If the people involved have another culture with a comparable language, an instrument used in a nation other than the one in which it was created may need modification [5].

When it comes to attitudes toward inclusive education, the Multidimensional Attitudes toward Inclusive Education Scale (MATIES) was developed to 
effectively measure affective, cognitive, and behavioral aspects of attitudes in inclusive education, which includes physical, social, and curricular inclusion [6]. MATIES indicated if respondents possessed more positive or negative attitudes. Given the usage of Likertscales for scoring and the self-report format, the feasibility of administering and processing each of the questionnaires assessed in this research is comparable, with each being very simple to administer and score [7].

The purpose of this study was to carry out translation procedures of MATIES, adjust to the characteristics of the language and culture of the Indonesian people then develop it into an online instrument. The specific research question was "How is the translation procedure of MATIES into Bahasa Indonesian version?"

The overall goal throughout the processes was to produce a translation that was true to the original text's intent while also being easily understandable and meaningful to the Indonesian participants.

\section{METHODS}

The need to translate a questionnaire is often obvious from the start, particularly if one or more targeted groups require a language other than the one in which the questionnaire will be created. When research topics are addressed in countries where English is not the first language, translation of instruments designed in English and for an English-speaking community is frequently as a choice [8]. It is essential to translate quantitative measurements into the language of the culture being researched for investigations that will use quantitative measures [9].

The current research used both a back-translation technique and a decentering stance throughout the translation and cultural adaption processes. After the author received permission from the MATIES founder, the translation and adaptation process were conducted according to Guellemin's step.

\subsection{Maties}

MATIES developed by Dr. Marian Mahat, from Monash University. The MATIES examined teachers' attitudes toward inclusion in three aspects of psychology that are assessed: cognitive, behavioral, and affective levels. The MATIES examined what teachers were willing to do to improve inclusion in their classrooms (behavioural) and teachers' perceptions of their competence, confidence, impatience, and aggravation in regard to the inclusion of children with special needs (affective) [7].

\subsection{Instrument Translation Cross-cultural Method: Guillemin, Bombardier, and Beaton's criteria}

There are two main approaches for instrument creation in cross-cultural research. In the first case, an instrument is created for usage in two languages, with the premise that none of the languages is the source language. The elements are changed in a reciprocal procedure, which allows for tight alignment of the two versions. Rather than creating a new instrument, researchers in the second case adapt an already established and validated instrument in a frequently used target culture and language [11]. The need to translate a questionnaire is often obvious from the start, particularly if one or more targeted groups require a language other than the one in which the questionnaire will be created [12]. The following recommendations focus on the critical issues that must be addressed to ensure the tool's sensitivity in the target culture.

The first step of forwarding translation involved adhering to Guillemin, Bombardier, and Beaton's criteria [5].

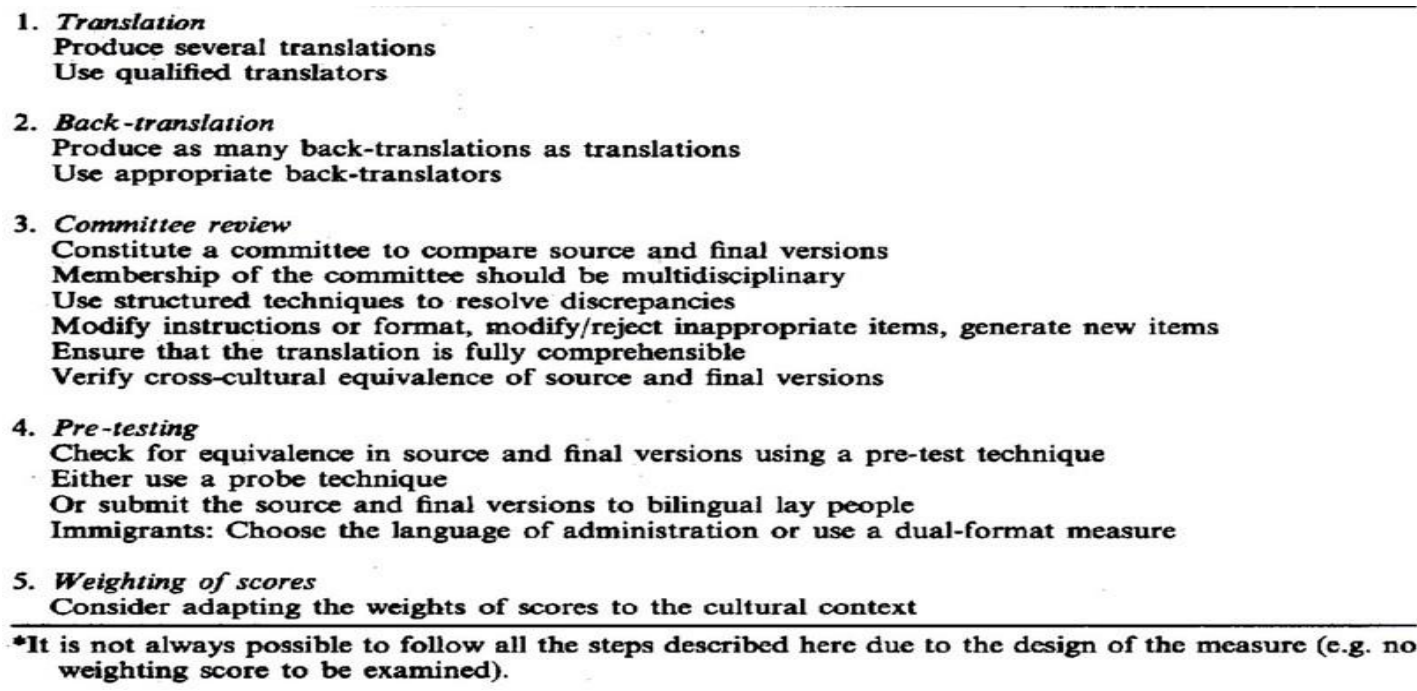

Figure 1 The Cross-cultural instrument translation procedure [5]. 


\subsubsection{Multiple translations should be produced}

When at least two separate translators work on a translation, the quality is increased. This enables the identification of inconsistencies and different interpretations of unclear elements in the original. The quality will be enhanced even more if each translation is carried out by teams rather than by single people, who are more prone to add personal idiosyncrasies.

\subsubsection{Collaborate with translators who are competent}

Additionally, the translators' credentials and qualities are critical. Individuals with advanced degrees may be culturally dissimilar to the target audience. Preferably, translators should translate into their own language. Some of them should be aware of the purposes for which the material is being translated and the ideas involved in order to provide a more trustworthy restoration of the intended measurement. Other translators who are unfamiliar with these goals and ideas may be able to extract unexpected interpretations from the source tool [5].

\subsubsection{Back-translation process}

The forward translation was completed by the author, who was familiar with the original intent of the questionnaire. She is Indonesian born and growth and also fluent in English who spending several years in the Europe.
For the backward translation, the author collaborated with the English-Indonesian language expert who is familiar with instrument translation. For the semantic area checked and validated by Bahasa Indonesia expert who born and focus on Translation.

\section{RESULTS AND DISCUSSION}

This contrasts with the scant descriptions of instrument and scale translation procedures seen in study papers. Frequently, it is stated in a single phrase that simply states that the questionnaire was translated. Interpretation is inextricably linked to the process of absorbing the original language's connotations and moving beyond literal meaning. We have shown in this research that cultural adaptation via the use of a decentering attitude and negotiated consensus may improve the content of an instrument when translated into another language and the process of back- translation. Cultural adaptation occurred throughout the process and is not seen as a distinct phase. This meant that words and phrases were questioned and debated at different phases of the process, as they emerged.

While the translation process went smoothly, a few issues arose during the project that were resolved. The advance translators encountered considerable difficulty in the initial phase in finding an adequate match for certain English words in Bahasa Indonesia.

When the English back-translated versions were compared to the original, one item's phrasing looked odd in English.

Table 1. MATIES Forward-translation English to Indonesia (items taken from Mahat [6])

\begin{tabular}{|c|l|}
\hline No & \multicolumn{1}{|c|}{ Item } \\
\hline 1 & $\begin{array}{l}\text { Saya percaya bahwa sekolah inklusif adalah sekolah yang memungkinkan kemajuan akademik semua } \\
\text { siswa terlepas dari kemampuan mereka }\end{array}$ \\
\hline 2 & Saya percaya bahwa siswa penyandang disabilitas harus belajar di SLB \\
\hline 3 & Saya percaya bahwa inklusi memfasilitasi perilaku yang sesuai secara sosial di antara semua siswa \\
\hline 4 & $\begin{array}{l}\text { Saya percaya bahwa setiap siswa dapat belajar dalam kurikulum umum jika kurikulum disesuaikan } \\
\text { untuk memenuhi kebutuhan masing-masing }\end{array}$ \\
\hline 5 & $\begin{array}{l}\text { Saya percaya bahwa siswa penyandang disabilitas harus dipisahkan karena terlalu mahal untuk } \\
\text { memodifikasi lingkungan fisik sekolah. }\end{array}$ \\
\hline 7 & $\begin{array}{l}\text { Saya percaya bahwa siswa penyandang disabilitas harus berada di SLB sehingga mereka tidak } \\
\text { mengalami penolakan di sekolah reguler }\end{array}$ \\
\hline 8 & $\begin{array}{l}\text { Saya merasa frustrasi ketika saya mengalami kesulitan berkomunikasi dengan siswa penyandang } \\
\text { saya }\end{array}$ \\
\hline
\end{tabular}




\begin{tabular}{|c|l|}
\hline 9 & Saya merasa kesal ketika saya tidak dapat memahami siswa penyandang disabilitas \\
\hline 10 & $\begin{array}{l}\text { Saya merasa tidak nyaman memasukkan siswa penyandang disabilitas di kelas reguler dengan siswa } \\
\text { lain yang bukan penyandang disabilitas }\end{array}$ \\
\hline 11 & $\begin{array}{l}\text { Saya merasa bingung saat siswa penyandang disabilitas diikutsertakan dalam kelas reguler, terlepas } \\
\text { dari tingkat disabilitasnya }\end{array}$ \\
\hline 12 & $\begin{array}{l}\text { Saya merasa frustrasi ketika saya harus menyesuaikan kurikulum untuk memenuhi kebutuhan individu } \\
\text { seluruh siswa }\end{array}$ \\
\hline 13 & $\begin{array}{l}\text { Saya bersedia mendorong siswa penyandang disabilitas untuk berpartisipasi dalam semua kegiatan } \\
\text { sosial di kelas reguler. }\end{array}$ \\
\hline 15 & $\begin{array}{l}\text { Saya bersedia menyesuaikan kurikulum untuk memenuhi kebutuhan individu semua siswa terlepas dari } \\
\text { kemampuan mereka. } \\
\text { dengan dukungan yang diperlukan. }\end{array}$ \\
\hline 16 & $\begin{array}{l}\text { Saya bersedia untuk memodifikasi lingkungan fisik untuk mengikutsertakan siswa penyandang } \\
\text { disabilitas di kelas reguler }\end{array}$ \\
\hline 17 & $\begin{array}{l}\text { Saya bersedia menyesuaikan teknik komunikasi saya untuk memastikan bahwa semua siswa dengan } \\
\text { gangguan emosi dan perilaku dapat berhasil diikutsertakan ke dalam kelas regular }\end{array}$ \\
\hline 18 & \begin{tabular}{l} 
Saya bersedia menyesuaikan penilaian siswa agar pendidikan inklusif dapat berlangsung \\
\hline
\end{tabular} \\
\hline 14
\end{tabular}

Table 2. MATIES Backward-translation Indonesia to English (items taken from Mahat [6])

\begin{tabular}{|c|c|}
\hline No & Item \\
\hline 1 & $\begin{array}{l}\text { I believe that an inclusive school is the one that permits academic improvement (progression) of all } \\
\text { students regardless their ability }\end{array}$ \\
\hline 2 & I believe that students with disability should be taught in special education schools \\
\hline 3 & I believe that inclusion facilitates socially appropriate behavior among all students \\
\hline 4 & $\begin{array}{l}\text { I believe that every student can learn in the regular curriculum of the school if the curriculum is adapted } \\
\text { to meet their individual needs. }\end{array}$ \\
\hline 5 & $\begin{array}{l}\text { I believe that students with disability should be separated because it is too expensive to modify the } \\
\text { physical environment of the school }\end{array}$ \\
\hline 6 & $\begin{array}{l}\text { I believe that students with disability should be in special education schools so that they do not } \\
\text { experience rejection in the regular school }\end{array}$ \\
\hline 7 & I get frustrated when I have difficulty communicating with students with disability \\
\hline 8 & I get upset when students with disability cannot keep up with the day-to-day curriculum in my classroom \\
\hline 9 & I get irritated when I am unable to understand students with disability \\
\hline 10 & $\begin{array}{l}\text { I feel uncomfortable to include students with disability in a regular classroom with other students without } \\
\text { disability }\end{array}$ \\
\hline 11 & $\begin{array}{l}\text { I feel confused when students with disability are included in the regular classroom, regardless of the level } \\
\text { of the disability }\end{array}$ \\
\hline
\end{tabular}




\begin{tabular}{|c|c|}
12 & I feel frustrated when I have to adapt the curriculum to meet the individual needs of all students \\
\hline 13 & $\begin{array}{l}\text { I am willing to encourage students with disability to participate in all social activities in the regular } \\
\text { classroom }\end{array}$ \\
\hline 14 & $\begin{array}{l}\text { I am willing to adapt the curriculum to meet the individual needs of all students regardless of their ability } \\
\text { I am willing to physically include students with severe disability in the regular classroom with the } \\
\text { necessary support }\end{array}$ \\
\hline 16 & $\begin{array}{l}\text { I am willing to modify the physical environment to include students with a disability in the regular } \\
\text { classroom }\end{array}$ \\
\hline 18 & $\begin{array}{l}\text { I am willing to adapt my communication techniques to ensure that all students with an emotional and } \\
\text { behavioral disorder can be successfully included in the regular classroom }\end{array}$ \\
\hline
\end{tabular}

While we were able to get translators, other researchers claim that the most challenging aspect of utilizing Guillemin's back-translation technique is assembling enough multilingual individuals to conduct the procedure. As an alternative, employing just two independent bilingual translators, one to translate and one to back-translate, is another possibility. However, even when the back translation is inadequate, it may seem to be such. This is because a skilled or proficient translator may achieve semantic and content equivalence between the source and back-translated versions, even if the source to target language translation is inadequate.

Additionally, the process of reverse translation is time intensive and sometimes extensive. Researchers may be constrained by a lack of resources (e.g., time, money, and accessibility and availability of bilingual individuals), in addition to the fact that none of the instrument translation methods is ideal. As a result, instrument translation in cross-cultural research should use a mix of methods.

\section{CONCLUSION}

The authors of this research complete the translation of the MATIES into a culturally and semantically suitable instrument for assessing falls efficacy in relation to fear of falling in community-dwelling Indonesian older people, using Guillemin's process and methods. The results of this research showed that the MATIES (Indonesian) version is conceptually, semantically, and content equivalent to the original MATIES, with some slight modifications. Further study with bigger samples will be conducted to ascertain the measure's psychometric characteristics and to elucidate fear of falling among Indonesian older people.

\section{AUTHORS' CONTRIBUTIONS}

Khofidotur Rofiah is a $\mathrm{PhD}$ student in Uniwersytet Pedagogiczny im. Komisji Edukacji Narodowej w
Krakowie, Krakow, Poland. Also she is a lecturer at the Special Education Department, Faculty of Education, Universitas Negeri Surabaya, Indonesia. She has published several papers, and has interests in students with Indonesian inclusive education, teacher attitudes, communication alternative and deaf community.

\section{ACKNOWLEDGMENTS}

The authors would like to thank the participants of this study for their valuable contribution. Also, special thanks give to Universitas Negeri Surabaya, Indonesia which funded and supported to conduct this research.

Special thanks dedicated to Prof. Marian Mahat, the MATIES author from Monash University for giving the permission to translate and all research interest.

\section{REFERENCES}

[1] M. Friend and W.D. Bursick, Including Students with Special Needs. US: Pearson Inc., 2012.

[2] K. Rofiah, K. Sheehy, S. Widayati, and Budiyanto, "Fun and the benefits of Sign Supported Big Books in mainstream Indonesian kindergartens," International Journal of Early Years Education, pp. 1-15, 2021. DOI: 10.1080/09669760.2021.1956440

[3] B.S.S. Callicutt, "A Comparison of Perspectives of Special and Regular Education Teachers on Inclusive Education," Ph.D. dissertation, Liberty University, Lynchburg, US, 2020. Retrieved from https://digitalcommons.liberty.edu/doctoral/247 2

[4] E. Avramidis and B. Norwich, "Teachers' attitudestowards integration / inclusion: a review of the literature," European Journal of Special 
Needs Education, vol. 17, no. 2, pp. 129-147, 2002. DOI: $10.1080 / 08856250210129056$

[5] F. Guillemin, C. Bombardier, and C. Beaton, "Cross-Cultural Adaptation of Health-Related Quality of Life Measures: Literature Review and Proposed Guidelines," Journal of Clinical Epidemiology, vol. 46, no. 12, pp. 1417-1432, 1993. DOI: 10.1016/0895-4356(93)90142-N

[6] M. Mahat, "The Development of a Psychometrically-Sound Instrument to Measure Teachers' Multidimensional Attitudes toward Inclusive," International Journal of Special Education, vol. 23, no. 1, 2008.

[7] D.L. Ewing, J.J. Monsen, and S. Kielblock, "Teachers' attitudes towards inclusive education: a critical review of published questionnaires," Educational Psychology in Practice, vol. 34, no. 2,pp. 150-165, 2017. DOI:10.1080/02667363.2017.1417822

[8] E.O.C. Hall, M.E. Wilson, and J.A. Frankenfield, "Translation and restandardization of an instrument: the Early Infant Temperament Questionnaire," Journal of Advanced Nursing, vol. 42, no. 2, 2003. DOI: 10.1046/j.13652648.2003.02599. $\mathrm{x}$

[9] W. Maneesriwongul and J.K. Dixon, "Instrument translation process: a method review," Journal of Advanced Nursing, vol. 48, no. 2, pp. 175-186, 2004. DOI: $10.1111 /$ j.1365-2648.2004.03185.x

[10] S. Kielblock, "Inclusive Education for All: Development of an Instrument to Measure the Teachers' Attitudes," Ph.D. dissertation, Philosophy Dept., JLU, Giessen, Germany, MU, Sydney, Australia, 2018.

[11] S. Phongphanngam and H.W. Lach, "Crosscultural Instrument Translation and Adaptation: Challenges and Strategies," Pacific RIM International Journal of Nursing Research (PRIJNR), vol. 23, no. 2, pp. 170-179, 2019. Retrieved from https://he02.tcithaijo.org/index.php/PRIJNR/article/view/12903 2

[12] J. Harkness and A. Schoua-Glusberg, "Questionnaires in translation," in Cross-cultural survey equivalent, J. Harkness, Ed., ZUMANachrichten Spezial, pp. 87-126, 1998. Retrieved from https://nbnresolving.org/urn:nbn:de:0168- ssoar-49733-1 